\title{
Is constitutionalized media freedom only window dressing? Evidence from terrorist attacks
}

\author{
Christian Bjørnskov ${ }^{1,2} \cdot$ Stefan Voigt ${ }^{3,4}$ (D)
}

Received: 1 October 2019 / Accepted: 8 February 2020 / Published online: 15 February 2020

(c) The Author(s) 2020

\begin{abstract}
Media freedom is often curtailed in the wake of terrorist attacks. In this contribution, we ask whether constitutional provisions that are intended - directly or indirectly - to protect media freedom affect the degree to which press freedom is curtailed after terrorist incidents. We find that neither provisions explicitly protecting media freedom nor provisions that might protect media freedom indirectly (such as those guaranteeing the independence of the judiciary) mitigate the post-terror curtailment of press freedom.
\end{abstract}

Keywords Press freedom - Media freedom - Terrorism $\cdot$ Freedom of expression · Judicial independence $\cdot$ Constitutional political economy $\cdot$ State of emergency $\cdot$ Emergency provisions

JEL Classification $\mathrm{K} 40 \cdot \mathrm{Z} 13$

\section{Introduction}

Ever since the time of Edward Burke, the press has been hailed as the "fourth estate", emphasizing its important role both as a government watchdog as well as a forum wherein possible policy changes can be discussed and advocated. The press can fulfil those important functions only if it enjoys considerable freedom. The responsibilities of the press, and the freedom to fulfil them, especially are important in situations in which the government, other politicians, the civil service or influential special interests have incentives to pursue policies that are not endorsed by the public at large. As is the case for other elements of well-functioning modern institutions, most modern constitutions are intended to do exactly that: protect the press and other media from political control.

Stefan Voigt

stefan.voigt@uni-hamburg.de

1 Department of Economics, Aarhus University, Århus, Denmark

2 Research Institute of Industrial Economics, Stockholm, Sweden

3 Institute of Law and Economics, University of Hamburg, Hamburg, Germany

4 CESifo, Munich, Germany 
Terrorism and terrorist threats have become a salient topic in most Western countries at least since al Qaeda's attacks on New York City and Washington, D.C., in September 2001. Soon afterwards, many politicians and political parties argued that existing legislation failed to provide protection against terrorism; in some countries, governments have introduced wide-ranging anti-terror legislation, which can include the possibility of curtailing media freedom (Dragu 2011). The stated reason typically is that restrictions on the press reduce the likelihood of future terrorist events and increase the chances of apprehending the perpetrators. Since terrorists aim at intimidating audiences beyond that of the immediate victims (Enders and Sandler 2012), media publicity for such events could further the terrorists' cause. This observation is also used as a justification for curbing media freedom, although terrorist incidents also may serve as pretexts justifying restricting the media. Media freedom may be violated for reasons completely unrelated to terrorism or any other tangible threats.

Examples in which terrorist threats serve as justifications for limiting media freedom abound: Singapore, for example, passed a "Public Order and Safety (Special Powers) Act 2018 " that allows her ministry of home affairs to ban media coverage of terrorist attacks entirely. Given that the identification of "terrorism" is not always crystal-clear ex ante, that law is likely to reduce media freedom in quite a general way. Singapore, on most indicators, already ranks in the bottom quintile of media freedom globally. But such legislation is not confined to countries without traditions of media freedom. The United Kingdom, for example, passed its "counter-terrorism and border security bill" into law on February 12,2019 . The bill was criticized for having extremely worrying implications not only for media freedom, but also for the protection of journalistic news sources (The Guardian Oct 25,2018 ). After a failed coup in 2016, Turkey closed many news outlets and jailed more than three hundred journalists on charges of having aided a terrorist organization. ${ }^{1}$

In those and a number of other cases, legislative action often was justified by referring to a perceived 'public demand' for harsher punishments in order to combat terrorism, and a growing acceptance of the need to change the political balance between security and liberty, to the latter's detriment (Dragu 2011). However, the demand for additional legislation also may originate with special interests within the state apparatus, such as the police and intelligence services, or simply result from politicians' own re-election motives if voters reward politicians who appear to be "tough" on terrorism. In general, media freedom is a double-edged sword for governments: On the one hand, it can help alleviate agency slack at lower level administrative units whose inefficiencies are reported by the press (Egorov et al. 2009). In that sense, media freedom ameliorates principal-agent problems within governments by reducing informational asymmetries. On the other hand, in emotion-charged situations, such as terrorist incidents, the media might criticize governments for not having taken appropriate preventive actions. ${ }^{2}$ It has been shown that re-election prospects of governments dramatically fall even after a single terrorist incident (Gassebner et al. 2008). To support their re-election efforts, governments can have incentives to curb media freedom after a terrorist attack. Doing so not only curtails civil liberties, but also can have adverse

\footnotetext{
1 A list of names, media outlets and dates of arrest can be found here: https://turkeypurge.com/journalism -in-jail. As of November 1, 2019, the list contained 319 names, of which 180 were still under arrest.

2 Sunstein and Zeckhauser (2011) show that emotionally charged events lead people to be fearful and to neglect adequately taking into account the probability of such events occurring. The likely consequence, namely so-called action bias, especially would be likely if the relevant actors (in our case, the government) expect to be able to claim credit for responding to the threat.
} 
effects on governmental accountability, including corruption and regulatory overreach (Brunetti and Weder 2003; Besley and Prat 2006).

Constitutional constraints are, among other things, designed to protect the governed citizenry against exactly such political actions; changes to statutory law as in Singapore and the United Kingdom must be consistent with the constraints on policymaking defined by the constitution (Buchanan and Tullock 1962). Later scholars have considered the tradeoffs between governmental reactions to terrorism and constitutional safeguards for individual freedom (Bernholz 1979). In this paper, we ask whether constitutional provisions actually protect media freedom in the aftermath of terrorist attacks. Given that civil liberties and media freedom, in particular, might be abridged following terrorist attacks, we ask whether constitutional provisions that are supposed to protect the media are successful in mitigating such restrictions.

Employing a panel dataset of up to 83 countries observed between 1993 and 2013, we find a number of unexpected results. First, simple bivariate correlations between levels of realized media freedom and different levels of formal constitutional guarantees of it show that countries not protecting press freedom explicitly at all fare best, whereas countries with elaborate formal protections fare worst. Multivariate analysis in which terrorist events are taken into account confirms the informal evidence from simply eyeballing the raw data: when explicitly recognizing the possibility that media freedom might be protected against governmental encroachment by (1) an independent judiciary (formalized by its constitutional protections) or by (2) specific provisions recognizing that states of emergency can be declared (also formalized in the constitution), we find that neither provision mitigates reductions in de facto media freedom following terrorist activities, while their combination may even make encroachments on media freedom more likely.

The rest of the paper is structured as follows. Section 2 briefly summarizes the main insights regarding both the effects of media freedom as well as its determinants. In Sect. 3, we develop a number of hypotheses explaining why media freedom could be curtailed in the wake of a terrorist attack and what provisions might help to counteract that possibility. Section 4 describes typical constitutional provisions for protecting media freedom as well as special provisions that enable governments to curtail it in a state of emergency. That section also presents our measures of both de jure and de facto media freedom. In Sect. 5, we present additional data and our estimation approach. The results are discussed in Sect. 6. Section 7 concludes.

\section{Media freedom: a brief survey}

Economic research on both the determinants and the effects of media freedom began relatively late. Regarding its effects, Sen's (1984) contribution was an early study. He observed that, at the time, India had never experienced a famine-and believed that the free Indian press served as a watchdog over the Indian government, incentivizing it to act swiftly to prevent people from starving. Following up on Sen's lead, Besley and Burgess (2001) looked into the actions taken by Indian state governments following food shortages, finding governmental responsiveness to be positively correlated with newspaper circulation. By now, a consensus exists that a free press makes governments more accountable and less prone to corruption (see e.g., Brunetti and Weder 2003; Chowdhury 2004).

More recent research has studied the relevance of more detailed media characteristics, such as public versus private ownership (Djankov et al. 2003), the effects of media capture 
by government (Besley and Prat 2006), and the effects of the competitiveness of media markets (Gehlbach and Sonin 2014). Some interest in the determinants of media freedom is evident, with Stier (2015) observing that-quite generally-democracies enjoy more media freedom than autocracies. Within autocracies, he finds that elected autocrats, monarchies and military regimes have the freest media, whereas communist ideocracies have the least free media. VonDoepp and Young (2012) find that media harassment intensifies when governments confront more uncertainty, such as facing major protests, coups and conflict onsets, while Bjørnskov et al. (2018) find that only successful coups against democracies result in less media freedom.

Kellam and Stein (2016) are concerned with the reasons for curbing media freedom in presidential democracies. They propose to distinguish between explanations traceable to differences in ideological preferences, on the one hand, and different institutional provisions on the other. According to them, left-leaning presidents who act in the context of a conservative media are more likely to curb media freedom than are conservative presidents. Regarding institutional constraints, a decline in media freedom is more likely if the president has stronger executive powers. It is less likely if the constraints on the executive are stronger, and where the judiciary enjoys more independence. Although most of the hypotheses are supported by empirical results, the literature nevertheless is fairly recent and often interested in specific aspects of media freedom, such as the consequences for it of the form of government or media freedom's determinants in specific regions only.

Finally, fascinating evidence has been reported on how important the media are considered to be by the government versus legislators and judges. Peru offers a unique opportunity for answering that question by relying on a specific case, namely Vladimiro Montesinos Torres, the security advisor to former Peruvian president Alberto Fujimori, who documented Fujimori's handing out of bribes in considerable detail. According to McMillan and Zoido (2004), the legislator paid the largest bribe received USD 20,000, the representative of the judiciary (actually not a judge, but the general manager of the judicial power) received 55,000 USD, and José Francisco Crousillat of America Television (Channel 4) signed a contract entitling him to USD 9,000,000 (payable in six tranches of USD $1,500,000)$. If those numbers are interpreted as giving some indication of the perceived relevance of the media vis-a-vis legislators and judges, then favorable reporting obviously is valued highly.

Regarding possible interactions between terrorists, the media and government, relying on game theory would appear straightforward (Sandler 2014 summarizes the most relevant contributions). Yet, the few available studies have focused on the interactions between terrorists and the media, not explicitly including government as a relevant third actor. Rohner and Frey (2007), for instance, work with the reaction functions of both terrorists and the media and find two stable equilibria (a "no attack" equilibrium, consisting of no attacks/no reporting, and an "attack equilibrium" with a maximum number of attacks and maximum news coverage). Rohner and Frey also find an unstable equilibrium (with some attacks and some news coverage). From the point of view of both terrorists and the media, the "attack equilibrium" is preferred to the "no attack" one, an ordering not shared by the public. Based on their model, Rohner and Frey deduce a number of policy proposals that are intended to lessen sensationalist media reporting. Yet, for our purposes, government and its incentives would need to be taken explicitly into account, which is not the case in their model.

In a paper inquiring into the effects of media attention on terrorism, Jetter (2017) finds that additional reporting in the New York Times encourages more terrorist attacks in the country where the original acts were committed. Digging deeper into the possible 
relationship between news coverage of terrorist acts and the number of cross-border terrorist events, Asal and Hoffman (2016) propose to separate media freedom from press attention. One group of scholars interested in explaining the determinants of transnational terrorism argues that, given that terrorists aim to generate fear and anxiety in audiences beyond the targeted venue, an absence of domestic media freedom could lead to target substitution, inducing the terrorists to commit violent acts elsewhere. Asal and Hoffman challenge that view, finding that more attention to terrorism in the international press reduces the likelihood of cross-border terrorist attacks. One way of reducing cross-border terrorism therefore could be to encourage the international news media to extend their reporting on countries that have received little attention thus far.

In sum, solid evidence shows that a free media can have important effects on terrorist activities. Furthermore, some evidence shows that favorable reporting in the media is valued highly by governments and that the media is freer in democracies, whereas political uncertainty and general threats to the incumbent government undermine that freedom. Finally, the relationship between the media and terrorists is somewhat symbiotic. But we are not aware of any study asking whether terrorist events are a significant determinant of media freedom and - if that is the case-whether constitutional protections have any mitigating effect. Given the prominent place that terrorism and terrorist threats have occupied in public debates for two decades, that is an important gap, which we hope to help close in this contribution.

\section{Terrorism and media freedom: some hypotheses}

Constitutional provisions constitute the most basic layer of formal law and, as such, are highly salient. Nonetheless, many instances can be found in which governments are tempted not to comply with law regardless of whether it is statutory or constitutional. Since we assume non-compliance with constitutional constraints to be more visible, we also expect it to be more costly and, hence, less likely to occur than non-compliance with statutory law. Applied to the question at hand-given that constitutional constraints actually are complied with and function as intended-we expect realized levels of media freedom to be higher and more stable if guaranteed by the constitution.

In the event a terrorist attack takes place, the government might have numerous reasons to curb media freedom. The most benevolent reason would be the belief that extensive reporting of a terrorist incident would make it more difficult for police to arrest the perpetrators, or possibly even incentivize terrorists to carry out additional attacks. ${ }^{3}$ Moreover, extensive reporting on the atrocities committed by terrorists could create a "climate of fear" that extends beyond the attack's victims. Given the previously noted finding by Gassebner et al. (2008) that the re-election prospects of governments are lowered significantly by a terrorist incident, less benevolent governments have a strong incentive to

\footnotetext{
${ }^{3}$ In many countries, media outlets have adopted guidelines on how (not) to report on terror events, focusing on ethical as well as political concerns. One such example is provided in the editorial guidelines published by the BBC dealing with the language used when reporting terrorism (available at: https://www.bbc. co.uk/editorialguidelines/guidance/terrorism-language/guidance-full). The UNESCO (2017) has published a handbook for journalists entitled "Terrorism and the Media" (downloadable at https://unesdoc.unesco.org/ ark:/48223/pf0000247074), which is available in many languages and tries to set some standards for reporting.
} 
constrain reporting about terrorist incidents in order to stay in power. Likewise, a critical press also can pose a threat to incumbents if it helps potential opponents of the current government coordinate anti-government actions, such as demonstrations. Finally, a terrorist incident therefore might simply be a welcome pretext for government to curtail media freedom. ${ }^{4}$

In sum, numerous reasons exist for expecting media freedom in general to be abridged following a terrorist attack. However, in its attempts to curtail media freedom in such a situation, almost all governments formally are constrained by a variety of constitutional provisions. One is the constitutionally guaranteed protection of freedom of expression already discussed above, but, as we argue in the following, that protection may interact with at least two more potentially relevant provisions.

First, if government tries to abridge media freedom, although it is constitutionally protected, actual restrictions seem less likely if those affected have standing to take their case to court. If so, it is important that government cannot interfere in the court's decision-making, or - in other words - that the court is independent of the government. We thus expect less reduction in media freedom subsequent to a terrorist attack if media freedom and judicial independence are guaranteed constitutionally.

Second, most countries have constitutionalized emergency provisions spelling out (1) how a state of emergency can be declared and (2) what additional competencies the government enjoys once a state of emergency is in effect (Bjørnskov and Voigt 2018). Given that the constitution includes specific emergency provisions, they could have important effects on media freedom. By confining restrictions on media freedom to the emergency period proper, such provisions could help maintain high levels of media freedom in "normal", i.e., non-emergency, times. Conversely, when the constitutional emergency provisions grant the government power to violate media freedom in emergencies, their existence also could lead to tighter restrictions on the press after a terrorist attack.

We propose to summarize our theoretical conjectures by stating four testable hypotheses. Reductions in media freedom following a terrorist attack are less likely when (1) the constitution explicitly protects media freedom. Such restrictions are, however, more likely when (2) constitutional emergency provisions allow such action simply because all constitution-abiding governments then can curtail media freedom without violating any other constitutional constraint. Abridgement of media freedom is less likely when (3) an independent judiciary credibly can enforce constitutional protections of media freedom (and constitutional emergency provisions do not allow curbing it). Finally, (4) reductions in media freedom are most likely when emergency provisions permit them and the judiciary is not independent from government.

\footnotetext{
${ }^{4}$ We note that if government reactions to terrorist attacks are benevolent and meant only to deal with the immediate threat, any reduction in media freedom observed soon after a terrorist attack should be reversed within a reasonable time frame. When, in contrast, government uses terrorist incidents as a welcome pretext for curbing media freedom, it would be unlikely to observe only temporary reductions in press freedom.
} 


\section{Constitutional provisions to safeguard media freedom}

\subsection{Measuring de jure protection of media freedom}

Before presenting the indicators we have adopted for quantifying a number of relevant constitutional provisions, a definition of media freedom is in order. Freedom of expression is a broad concept, encompassing both freedom of the press and other types of media. In Article 19 of the Universal Declaration of Human Rights (UN 1948), it is defined as a "right to freedom of opinion and expression; this right includes freedom to hold opinions without interference, and to seek, receive, and impart information and ideas through any media regardless of frontiers." In the following, we take that definition as our starting point for both measurement and interpretation of our findings.

We focus herein on the protection of media freedom as defined by the constitution and not merely by statutory law. Given that it may be in the interest of a parliamentary majority to repress the media, for example, following a terrorist attack, the same majority can change or revoke any statutory protection for the media. As such, statutory protection of media freedom is no less fragile than ordinary political promises. Many constitutions treat freedom of the press and other media as part of the even broader concept of freedom of speech. Only a minority of constitutions separate freedom of speech from media freedom explicitly, supplying another reason for relying on a broad term; more specific ones could cause us to overlook relevant constitutional provisions.

Paragraph 77 of the Constitution of Denmark, for example, states that "Any person shall be entitled to publish his thoughts in printing, in writing, and in speech, provided that he may be held answerable in a court of justice. Censorship and other preventive measures shall never again be introduced." The Danish constitution thus makes it abundantly clear that the media are free of any censorship. The First Amendment to the US Constitution provides similarly unambiguous protection from any form of censorship by establishing that "Congress shall make no law ... abridging the freedom of speech, or of the press."

Both the Danish paragraph 77 and the US Constitution's First Amendment are examples in which the constitution makes clear that censorship is unconstitutional in all circumstances. However, most constitutions include a set of emergency provisions that allow restrictions on the press and other media during emergencies (Bjørnskov and Voigt 2018). While protecting freedom of speech under normal circumstances, the emergency provisions of the French constitution, for example, allow for substantial government-mandated restrictions on the press when a state of emergency has been declared. ${ }^{5}$

Such cases are easily coded, but a number of other cases require some judgment calls. The protection of media freedom in Bermuda's Constitution Order of 1968 is such a case. Paragraph 9 of that order states that: "(1) Except with his consent, no person shall be hindered in the enjoyment of his freedom of expression, and for the purposes of this section the said freedom includes freedom to hold opinions and to receive and impart ideas and information without interference, and freedom from interference with his correspondence." However, Section (2) of the same paragraph effectively allows for legislation that contravenes Section (1) when it is deemed reasonable:

\footnotetext{
5 Article 16 of the French constitution, which outlines its emergency provisions, allows the president, after due consultation, to "take measures required by these circumstances" and merely limits these measures to those that "provide the constitutional public authorities as swiftly as possible, with the means to carry out their duties.".
} 
in the interests of defence, public safety, public order, public morality or public health; or for the purpose of protecting the rights, reputations and freedom of other persons or the private lives of persons concerned in legal proceedings, preventing the disclosure of information received in confidence, maintaining the authority and independence of the courts, regulating telephony, telegraphy, posts, wireless broadcasting, television or other means of communication or regulating public exhibitions or public entertainments; or that imposes restrictions upon public officers or teachers, except so far as that provision or, as the case may be, the thing done under the authority thereof is shown not to be reasonably justifiable in a democratic society.

We adopt a conservative approach to coding media freedom by treating the foregoing list as an indication that media freedom can be curbed with relative ease within the bounds of the constitution. As such, if doubt exists about whether the constitution actually protects media freedom, or if additional provisions, such as is the case in Bermuda's Constitution Order, which in principle provides government with constitutional means to curb it, we code press freedom as not protected. While we therefore code Denmark and the United States with scores of 1, indicating full media freedom, we code Bermuda as a 0. Our main source of information is the Comparative Constitutions Project (CCP) (Elkins et al. 2009), which provides carefully coded information on constitutional provisions for most countries in the world until 2013.

Assessed in 2012, of the 83 countries in our full sample, 62 have constitutions that protect media freedom under normal circumstances, of which 22 allow restrictions in some kind of emergency. Conversely, 16 either have no constitutional provisions or their provisions are unclear; only five have what we consider as providing no protections for media freedom. ${ }^{6}$ We combine that information with whether or not media freedom is protected in general in order to create a dummy variable effectively capturing whether the press is not protected during emergencies, which also includes circumstances in which no protection is granted outside of emergencies. $^{7}$

We recognize that whenever the constitution permits limits on media freedom, either by being unclear or-as in the case of Bermuda-by stipulating circumstances in which the government can claim that restrictions are constitutional, it is up to a court to interpret the constitution and thus define the de jure limits within which the government can act. Similarly, even if the constitution explicitly bans any censorship or other limits on media freedom, a government with sufficient influence over court decisions and courts' de facto interpretations of the constitution still may be able to introduce legislation that restricts media freedom without facing constitutional repercussions. We therefore also develop a measure of high court independence in the following, based similarly on the way independence is defined in the constitution.

\footnotetext{
6 The five are Bermuda, Ecuador, Honduras, Montenegro and Turkey. Four of the countries are, incidentally, also countries in which the constitution provides particularly strong protections for the independence of judges sitting on high courts. The exception is Bermuda. We coded the Bermudan constitution ourselves, as that country is not included separately in the CCP because of its status as a British dependency.

7 In principle, we could have coded whether general constitutional protection of media freedom operates outside of declared states of emergency. However, our first tests revealed no empirical significance associated with general protections of media freedom. Our measure therefore can be interpreted as the protections accorded to press freedom during states of emergency.
} 


\subsection{Measuring de jure high court independence}

We measure judicial independence using information contained in the CCP to create an index of constitutional protections for the political independence of nations' high courts (Elkins et al. 2009). Our measure is the unweighted average of four indicators: (1) Does the constitution contain an explicit declaration regarding the independence of the central judicial branch of government? (2) Are judicial decisions rendered by the highest ordinary court final, or can they be challenged politically? (3) Is the government involved in nominating or approving the high court's chief justice? (4) Is the government involved in nominating or approving other members of the high court? The first two indicators are coded directly in the CCP; we assign a score of 1 if the constitution provides such explicit protection, 0.5 if the language is unclear, and 0 if the constitution provides no protections for the judiciary. For the third and fourth indicators, we assign similar scores if, alternately, the head of state, the head of government, or the government/cabinet is involved in the nomination of the chief justice/other members; if the same officials are involved in the approval of nominations of the chief justice/other members; and if the chief justice/other members are limited in terms of party affiliation, gender or religion. We normalize the full measure to a $0-1$ scale, with larger values indicating more de jure independence.

Within our sample, minimum independence is 0.125 , while the maximum is a perfect 1 , with an average of 0.57 (the value for Bermuda). ${ }^{8}$ We note that, in general, the partial correlation between constitutional protections for media freedom and high court independence is small $(r=-0.17)$. The same is the case for de jure independence of the high court and a de facto measure that we use throughout in the following. That de facto measure is the average of assessments of independence of the high courts and lower-level courts in the Varieties of Democracy database (Coppedge et al. 2016).

As illustrated in Fig. 5 in the appendix, the cross-sectional correlation between the de jure and the de facto measures of judicial independence in recent years (2008-2012 averages) is negative at $-0.19 .{ }^{9}$ The lack of any clear association between the de jure status and de facto judicial independence provides a first reason to doubt whether constitutional status actually ties the hands of the other branches of government. If not, the de jure measure of high court independence may instead reflect historical problems with limiting political interference. It thus is an open question whether constitutional provisions actually provide de facto protections for media freedom when politicians have incentives to renege on them. In the following, we provide a first answer to that question.

\footnotetext{
${ }^{8}$ Interestingly, Denmark is an excellent example of the disconnect between de jure and de facto independence; it is among the countries with the lowest de jure independence scores. However, in practice, the nomination and appointment of judges to the Danish courts is separated completely from government or politics. The process is instead handled by a committee of the Danish Court Administration, over which neither the minister of justice nor any other politician has instructive or discretionary power. As such, the Danish High Court is one of several examples of countries with very limited constitutional, but substantial de facto independence.

${ }^{9}$ A very similar pattern arises when using the alternative measure of judicial independence from Linzer and Staton (2015). Gutmann and Voigt (in press) inquire into the reasons explaining the puzzling negative correlation. They find that high-trust societies often manage to arrive at strong de facto judicial independence without recording it any formal law. In a sense, then, they find that formal legislation is a (very imperfect) substitute for social trustworthiness.
} 


\subsection{Measuring de facto protection of media freedom}

Constitutional protection of media freedom, as described in Sect. 4.1, refers to the letter of the law-in this case the constitution. However, it is well known that the actual extent of freedom enjoyed by the media might diverge substantially from what a constitution stipulates. Over the years, various organizations have produced indices that are meant to indicate the level of media freedom as implemented in practice. Two of those organizations focus on journalists' freedom, security, and personal safety, namely Reporters without Borders and the Committee to Protect Journalists. Freedom House, a New York based NGO interested in political, economic and civil freedoms has published a Freedom of the Press indicator ever since 1980, although the continuous indicator that we use here has been available only since 1993. The index covers 199 countries and territories and is based on a relatively minimalist, negative definition of press freedom that, for example, does not incorporate any consequences of press action, specify any particular political roles played by the media, or requires the media in general to abide by any form of quality criteria (Becker et al. 2007). Given both its breadth as well as its frequent use, we rely on Freedom House's index here; "Appendix 1" provides a detailed description. ${ }^{10}$

The Freedom House (2017) index of media freedom is coded on the basis of a number of questions and is distributed between 0 and 100, with lower scores indicating more freedom. As such, the index, which has been available since 1993, is a measure of press freedom's absence. Since 2001, the index has been decomposable into three constituent sub-indices on media laws and regulations, its political and economic environments. The index thus captures both political and de facto legal limits on media freedom, such as those created by governments attacking or closing media, bringing it under direct state control as well as potential restrictions created, for example, by the media's ownership structure. We reverse and rescale the index such that the largest average values we observe- the most free countries-score at approximately 0.94 to 0.95 (in Scandinavia and Switzerland) and the least free-i.e., the countries with the most restricted media-e.g., Azerbaijan (0.24), Belarus (0.15) and Cuba (0.06), score closer to zero. We do so such that both de jure and de facto measures are distributed on approximately similar scales, making the interpretation of effects straightforward.

\section{Control data and empirical strategy}

To identify the effects of terror events on media freedom, we rely on two separate measures of terrorism: the logarithm of the number of terrorist events in a given country to measure their frequency, and the logarithm of the number of individuals killed in those events, as a measure of their severity. Those data all are taken from the Global Terrorism Database (GTD 2017). We follow standard practice and count only the events that satisfy three criteria: (1) the attack is motivated by a political, socioeconomic, or religious motive; (2) the attack is intended to coerce, intimidate, or send a message to an audience wider than the immediate victims; and (3) the attack exceeds the boundaries set by international

\footnotetext{
10 The Varieties of Democracy Project also contains a variable on media freedom. We refrain from using it here because it is not always clear whether the focus is on a country's de jure or de facto media environment. Similarly, we refrain from using the alternative measure from Reporters without Borders owing to its more restricted coverage of countries and years.
} 


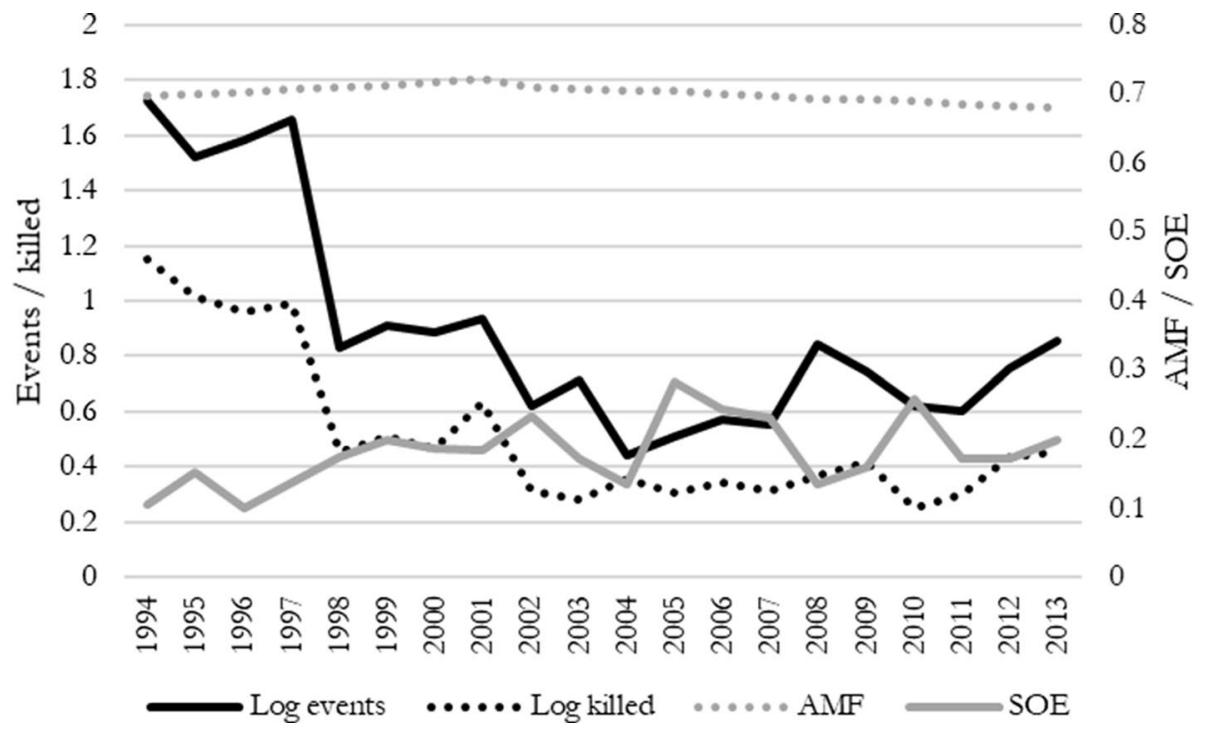

Fig. 1 Developments, 1994-2013. Note: The left-hand y-axis pertains to the log of the number of terrorist events and the log to the number killed in those events per year. The right-hand y-axis pertains to the average media freedom (AMF) and the share of countries that declared at least one state of emergency (SOE) per year

humanitarian law. In subsequent tests, we also draw data on events directed specifically against a government or police/military forces, and attacks in which the terrorists were armed with police- or military-grade weapons or attacked multiple targets.

Although the GTD covers most countries in the world, we restrict the present sample to a total of 60,649 episodes from 83 countries that satisfy a particular set of criteria. We first require that each country entering the sample have either democratic political institutions or formal constitutional rules that resemble those of Western democracies, and is not surrounded by countries that do not satisfy the same criteria. In other words, all countries in the sample have constitutions that de jure define the political system as democratic. Had we included societies with markedly different political institutions, wherein political processes, for example, are governed by single individuals, single tribes, or single undisputed regimes (as in communism or theocracy), we would not expect political independence to have the effects predicted by established public choice or political economy thinking. Second, in order to be able to compare constitutional efficacy, we require that the constitutional histories of the countries in our sample rest on similar foundations. In practice, our sample-selection methodology means that we exclude countries in which constitutional development starts with a first constitution written under the influence of the Soviet Union or similar intellectual tradition after World War II. Our sample thus includes Latin American countries that implemented their first constitutions simultaneously with most European countries, along with the Caribbean countries in which constitutional development rests on an even older British colonial tradition. Finally, we require that countries in the sample have sufficiently entrenched constitutions. That criterion means that we exclude most countries in Asia and Africa, where the constitutional order frequently is suspended and where regime transitions often are accompanied by non-transparent interim constitutions. Both of those features and the general lack of constitutional persistence in many societies beyond 


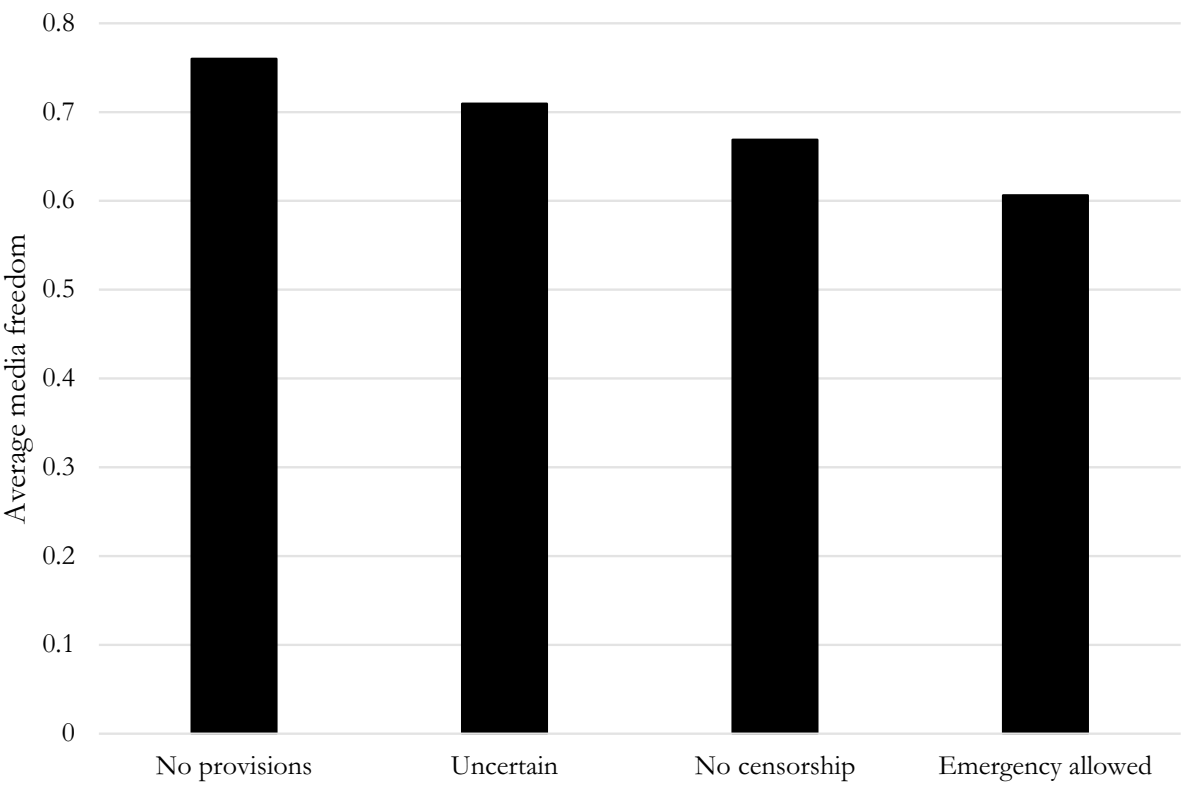

Fig. 2 Media freedom differences, constitutional provisions

the western tradition imply substantial uncertainty in constitutional interpretation. The 83 countries potentially entering our sample thus cover Europe, the Americas and Australasia, which ensures that their formal political institutions are similar, such that regular politics, political reactions and the role of the constitution formally are structured in similar ways. In the estimated models, this sample drops to a maximum of 78 countries owing to restricted availability of specific control variables.

Figure 1 illustrates the development over time of our two measures of terrorism-the average number of events and the average number of deaths per event-and the average level of media freedom (AMF) as well as the share of countries that in each year declared a state of emergency (SOE). As is clear in the figure, de facto media freedom has remained quite stable over time within our sample, reaching a high in 2001 and declining slightly thereafter. Conversely, terrorism fell substantially in the 1990s and shows only a slight increase in the new millennium, despite an actual increase in the likelihood that countries declare states of emergency. ${ }^{11}$

Figure 2 depicts average media freedom across four groups of countries, based on their constitutional provisions: countries with no provisions protecting media freedom, countries with uncertain provisions, countries that provide clear constitutional protections and, lastly, countries that allow censorship and restrictions of media freedom during states of emergency. Interestingly, the average level of de facto media freedom follows a sequence with countries without any formal protections having the highest average levels of media

11 Bjørnskov and Voigt (in press) find that an additional terrorist event increases the likelihood that the national government declares a state of emergency by $10 \%$. However, they also find that countries that have been in a state of emergency the previous year are substantially more likely to experience additional attacks. As such, there seems to be a strong association between terrorist events and emergencies, but causality most likely goes both ways and may reflect deeper characteristics. 
freedom, followed by those with uncertain provisions and then countries with clear protections in place. Finally, countries that do provide some constitutional protections for the media, but allow that freedom to be violated during emergencies exhibit the weakest media freedoms, on average. Table A1 in the appendix lists all countries in the sample, along with their overall media freedom averages, terrorism experiences (both variables), censorship and constitutional independences of their high courts.

Our basic model looks like this:

$$
\begin{aligned}
\text { De facto } \mathrm{mf}_{\mathrm{it}+1}= & \mathrm{a}+\mathrm{b} * \text { terror }_{\mathrm{it}}+\mathrm{c} * \text { de jure } \mathrm{mf}_{\mathrm{it}}+\mathrm{d} * \text { de jure } \mathrm{JI}_{\mathrm{it}} \\
& +\mathrm{e} * \text { allowance }_{\mathrm{it}}+\mathrm{f} * \mathrm{X}_{\mathrm{it}}+\mathrm{g} * \mathrm{D}_{\mathrm{i}}+\mathrm{h} * \mathrm{I}_{\mathrm{t}}+\mathrm{u}_{\mathrm{it}}
\end{aligned}
$$

Our baseline model is estimated alternately with two measures of terrorism (number of attacks or number of people killed) to ascertain the extent to which de jure media freedom (de jure $\mathrm{mf}$ ) predicts de facto freedom (de facto $\mathrm{mf}$ ), conditional on whether regular constitutional provisions or emergency provisions allow restrictions (allowance), the independence of the judiciary (de jure JI), and a set of controls, $X$. Variable $\mathrm{D}_{\mathrm{i}}$ is a set of country fixed effects and $I_{t}$ annual fixed effects; $u_{i t}$ is the error term. Since we hypothesize that terror events have less of a dampening effect on de facto media freedom when accompanied by either constitutionalized guarantees of (de jure) media freedom or constitutional guarantees of an independent judiciary, we interact them in some specifications.

The ensuing results are reported in Table 2, while the results of further tests are reported in Table 3. In the latter, we either add a triple interaction between all terrorism and both constitutional measures, or test the interaction between constitutionally guaranteed judicial independence and terrorism in two subsamples split according to emergency provisions-i.e., whether or not the emergency provision allows limits on media freedom during such extraordinary times. In both tables, we also report all main estimates with a sample only including observations from democratic country-years in order to make sure that our results are not driven by autocracies or anocracies.

We keep our specification quite parsimonious and include only a few control variables (the $\mathrm{X}$ vector). First, we add the logarithms of population size and real (purchasing-power parity) GDP per capita (both variables are from the Penn World Tables, mark 9; see Feenstra et al. 2015). From the GDP data, we also calculate a dummy for recessions that takes the value of 1 if the year-to-year growth rate is negative. Second, we enter a dummy for whether a coup attempt - failed or successful — was reported in a given year; we get the information for that variable from the database in Bjørnskov and Rode (in press). We also follow previous research in adding a few features of the country's political institutions and enter the Herfindahl-Hirschmann index of legislative fractionalization (or the lower house in bicameral systems), because political fractionalization per se may work as a veto institution creating de facto judicial independence. Following Kellam and Stein (2016), who found that in presidential systems, left-leaning governments are more likely to reduce media freedom than right-wing governments, we enter a measure of the political ideology of the incumbent government as an explanatory variable. In addition, we include a dummy for whether a terrorist attack occurred during a parliamentary election year, as governments might be particularly sensitive to critical media reports when they are trying to be re-elected. ${ }^{12}$ We derive those observations from the background database of Berggren and Bjørnskov (2017) and add a set of regime fixed effects from Bjørnskov and Rode's (in

12 The measure of government ideology is based on Berggren and Bjørnskov's (2017) categorization of all
parties in parliament into five groups: communist/unreformed socialist parties with scores of -1 , reformed
or modern socialist parties with scores of -0.5 , modern social democrats and non-ideological parties 
press) update of Cheibub et al. (2010), thereby capturing differences between parliamentary, weak presidential, and fully presidential democracies, and civilian autocracies, military dictatorships and absolutist monarchies.

Finally, we enter a full set of country, regime, and year fixed effects such that all results are driven by within-country variation relative to those explained jointly by international factors. The fixed effects imply that we are controlling for stable differences in threat levels, and international threat changes over time that are common to all countries in our sample. They also capture a set of other approximately time-invariant potential influences, such as social trust, historical experience and religious differences (cf. Engerman and Sokoloff 2008; Hillman and Potrafke 2018; Bjørnskov 2019).

As the fixed effects thus also capture long-run differences in constitutional histories and terrorist threats, we mainly see two potential sources of endogeneity. First, our estimates may be biased if country-specific changes in media freedom are known and foreseeable by terrorists, and that terrorists have clear interests in exploiting them before they are implemented. We cannot dismiss this problem, but note that the process of introducing constitutional changes tends to be very lengthy and that such changes are relatively rare in democracies. A second potential cause for endogeneity bias in our setting is that changes in media freedom could affect the likelihood of terrorist events, and also could affect the death tolls of those events indirectly if changes in media freedom reflect changes in underlying institutional quality or capacity (cf. Hoffman et al., 2013). While we do not believe either of those possibilities to be serious concerns because institutional quality tends to be very stable over time in relatively developed countries - and particularly so in democracies- the potential reactions of terrorists to institutional change might give rise to a positive bias (overestimation of the true effect) if restrictions on media freedom lead to more terrorist events, and a negative bias (underestimation) if they work in the intended way and lead to fewer events. One could argue further that the threat of terrorism could affect the de jure status of media freedom, making the estimates of our constitutional measures subject to endogeneity bias. However, given how rarely constitutions change and that provisions regulating media freedom and emergencies change even less frequently (cf. Bjørnskov and Voigt 2018), both the country-specific threat as well as the constitutional provisions are close to being timeinvariant. They are therefore subsumed in the country fixed effects and are not a source of endogeneity bias. As such, and following Nizalova and Murtazashvili's (2016) logic, the interaction terms and thus the heterogeneity of effects are free of endogeneity bias. In other words, our interacted results can still be interpreted as causal, as long as constitutional changes are rare, slowly implemented, and not affected directly by immediate changes in terrorist threats.

All data are summarized in Table 1, while, as noted, Table A1 in the appendix summarizes the main constitutional and terrorist data as country averages.

Footnote 12 (continued)

assigned scores of 0 , conservative parties with scores of 0.5 , and parties based in classical liberal principles with scores of 1 . The overall index of ideology thus positions economic policy and institutions on a standard left-to-right scale. 
Table 1 Descriptive statistics

\begin{tabular}{lrrl}
\hline Variable & Average & $\begin{array}{c}\text { Standard } \\
\text { deviation }\end{array}$ & Observations \\
\hline Press freedom & .698 & .211 & 1971 \\
Log no. of events & .908 & 1.316 & 1971 \\
Log no. of killed & .538 & 1.234 & 1971 \\
Target: government & .393 & .767 & 1971 \\
Target: police/military & .336 & .827 & 1971 \\
Type: heavily armed & .789 & 1.226 & 1971 \\
Constitutional independence & .574 & .210 & 1663 \\
De facto independence & 1.078 & 1.308 & 1827 \\
Emergency allowance & .164 & .296 & 1706 \\
Log population & 1.898 & 1.781 & 1761 \\
Log GDP per capita & 9.691 & .759 & 1761 \\
Recession & .181 & .385 & 1743 \\
Coup & .001 & .032 & 1971 \\
Legislative fractionalization & .363 & .185 & 1771 \\
Government ideology & .102 & .328 & 1771 \\
Election year & .273 & .446 & 1888 \\
\hline
\end{tabular}

\section{Main results}

We report our main results in Table 2, noting first that despite the relatively limited variability of media freedom-our dependent variable - in many countries, the specification does a decent job of explaining the within-country variation. However, we find only three significant control variables: countries that are more populous are likely to see less media freedom. While we find that media freedom tends to improve during recessions and, moreover, that de facto court independence is significant when it is entered. Conversely, we find weak evidence that more formal judicial independence ("constitutional court independence") is conducive to greater media freedom (columns 2 and 7), and that constitutionalized emergency provisions allowing restrictions on media freedom during states of emergency are correlated systematically with slightly higher levels of media freedom (columns 4 and 9). ${ }^{13}$ Throughout, we find very similar, but slightly less precise estimates when we restrict the sample to observations from democracies only; those results are reported in the lower panel of the table.

What is most important, we find that terrorism is on average associated with reductions in de facto media freedom (columns 1,2,6 and 7). Doubling the number of terrorist attacks or the numbers killed in those attacks is associated with a deterioration in actual media freedom of approximately one-half of a standard deviation. Yet, as we note in discussion of theoretical considerations, reasons exist for suspecting that the average association

\footnotetext{
13 The result holds independently of whether or not a state of emergency actually was declared. We must nevertheless caution against over-interpreting these results, as constitutional changes in those features are quite rare in our sample, and the specific results here therefore are deduced from a small number of events. In addition, we note that a finding (not shown) that the results are insensitive to whether a state of emergency was called indicate that changes in media freedom are not explained by Freedom House's coders treating emergencies as signals of repression.
} 


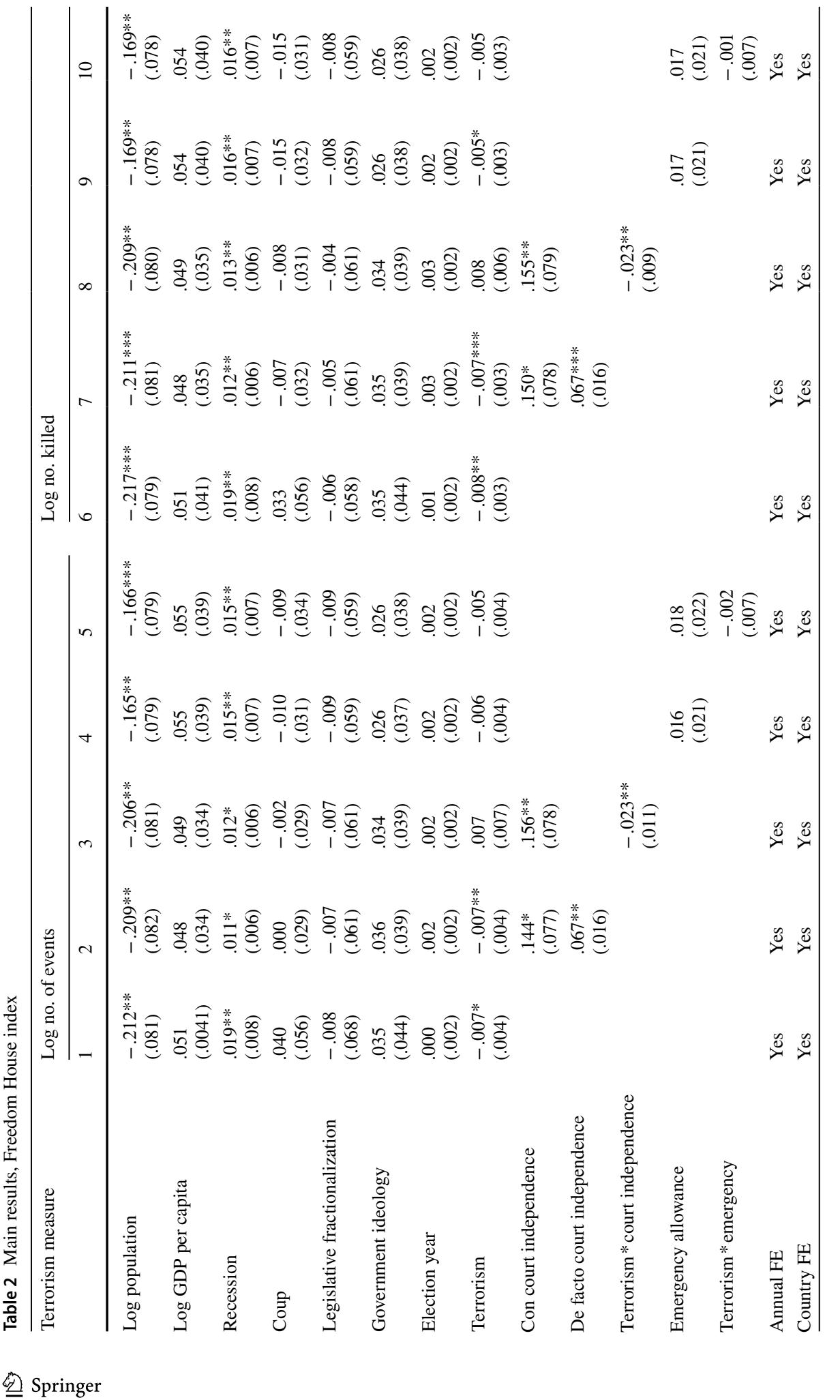




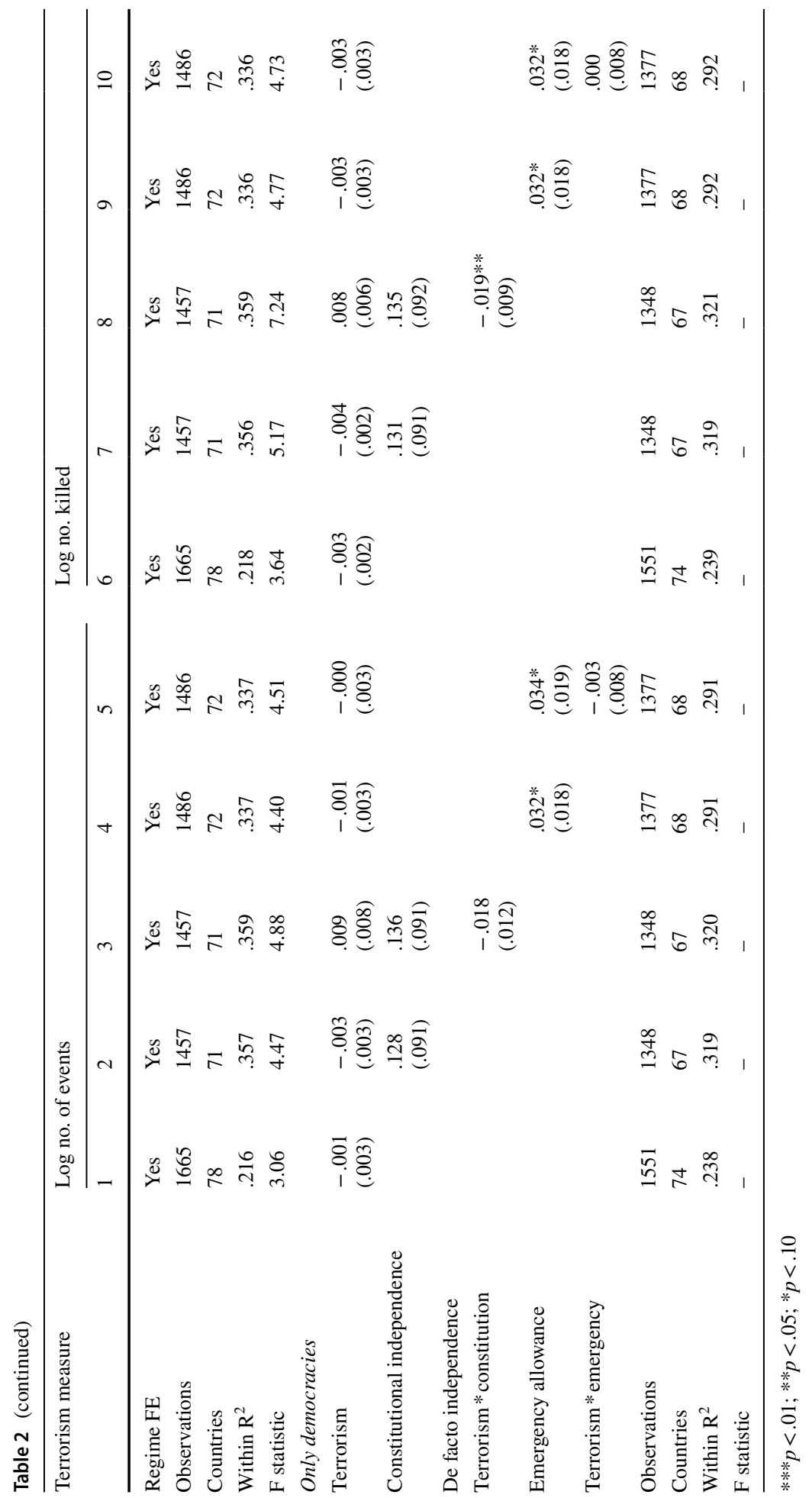




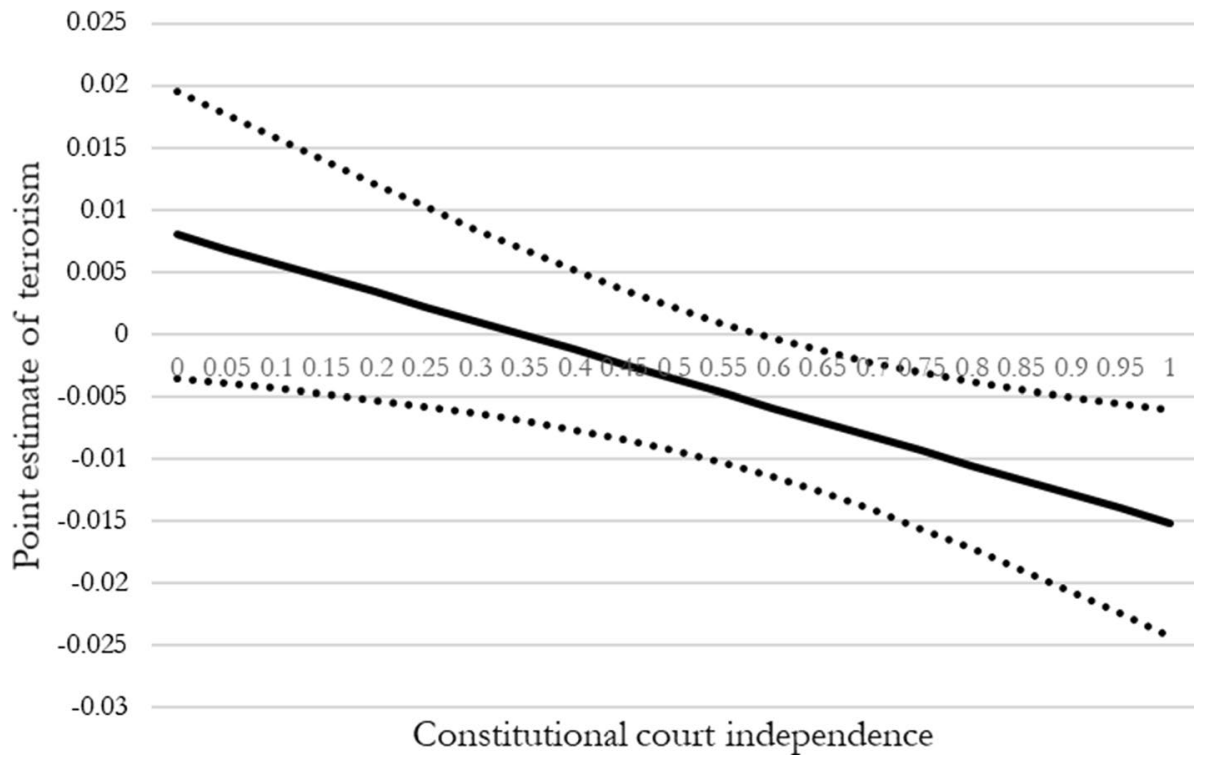

Fig. 3 Effects of terrorism, conditional on court independence

hides considerable heterogeneity across constitutional characteristics. In columns 3 and 8 , we therefore interact our terrorism measures with the constitutional independence of the high courts. ${ }^{14}$ In both cases, we find that the estimated effects of terrorism increase in the level of courts' constitutional independence and become significant as that independence strengthens. At the maximum index value of 1, i.e., the most careful constitutional protection of the independence of the high courts that we observe, the estimate is 0.156 in column 3 and 0.150 in column 7 ; the former is significant at $p<.05$, while the latter is significant at $p<.01$.

In Fig. 3, we plot the logged number of deaths during terrorist events, conditional on the de jure independence of the judiciary (i.e., the results reported in column 8). The figure illustrates how the association between terrorism and media freedom starts around zero for countries with very weak constitutional judicial independence and declines with the formal de jure level of court independence. The association becomes significantly negative at an index value exceeding approximately 0.6 , as indicated by the $95 \%$ confidence interval illustrated by the dotted lines. As such, the result also is politically relevant as constitutional independence is above that level in three-fourths of the countries in our sample.

In columns 5 and 10 of Table 2, we enter an interaction between terrorism and whether or not the emergency provisions allow the suspension of media freedom during such times. In both cases, we find that terrorism is insignificant when the emergency provisions do not allow for censorship, but significant when they do: the estimate conditional on allowing censorship in column 5 is -0.007 and the corresponding estimate in column 10 is -0.006 ; both are significant at $p<.05$. We thus do not find evidence of a significant difference in

\footnotetext{
${ }_{14}$ An additional benefit of the interactions in columns 3,5,8 and 10 is that they tend to alleviate the remaining endogeneity concerns (cf. Nizalova and Murtazashvili 2016).
} 
Table 3 Specific results

\begin{tabular}{|c|c|c|c|c|c|c|}
\hline & \multicolumn{3}{|c|}{ Log no. of events } & \multicolumn{3}{|c|}{ Log no. killed } \\
\hline & 1 & 2 & 3 & 4 & 5 & 6 \\
\hline \multicolumn{7}{|l|}{ Full baseline included } \\
\hline Terrorism & $\begin{array}{l}-.004 \\
(.008)\end{array}$ & $\begin{array}{l}-.006 \\
(.008)\end{array}$ & $\begin{array}{l}.023^{*} \\
(.013)\end{array}$ & $\begin{array}{l}-.003 \\
(.002)\end{array}$ & $\begin{array}{l}-.004 * * \\
(.002)\end{array}$ & $\begin{array}{l}.002 \\
(.007)\end{array}$ \\
\hline Con court independence & $\begin{array}{l}.156^{* *} \\
(.079)\end{array}$ & $\begin{array}{l}.139^{*} \\
(.073)\end{array}$ & $\begin{array}{l}-.027 \\
(.131)\end{array}$ & $\begin{array}{l}.159 * * \\
(.080)\end{array}$ & $\begin{array}{l}.148^{*} \\
(.076)\end{array}$ & $\begin{array}{l}-.057 \\
(.140)\end{array}$ \\
\hline Terrorism * court independence & $\begin{array}{l}-.004 \\
(.012)\end{array}$ & $\begin{array}{l}-.004 \\
(.014)\end{array}$ & $\begin{array}{l}-.037 * * \\
(.014)\end{array}$ & $\begin{array}{l}-.008 \\
(.006)\end{array}$ & $\begin{array}{l}-.009 \\
(.006)\end{array}$ & $\begin{array}{l}-.008 \\
(.007)\end{array}$ \\
\hline Emergency allowance & $\begin{array}{l}.002 \\
(.023)\end{array}$ & & & $\begin{array}{l}.003 \\
(.023)\end{array}$ & & \\
\hline Terrorism* emergency & $\begin{array}{l}.046^{*} \\
(.024)\end{array}$ & & & $\begin{array}{l}.042^{*} \\
(.022)\end{array}$ & & \\
\hline $\begin{array}{l}\text { Terrorism * emergency * court independ- } \\
\text { ence }\end{array}$ & $\begin{array}{l}-.071 * * \\
(.035)\end{array}$ & & & $\begin{array}{l}-.064 * * \\
(.031)\end{array}$ & & \\
\hline Annual FE & Yes & Yes & Yes & Yes & Yes & Yes \\
\hline Country FE & Yes & Yes & Yes & Yes & Yes & Yes \\
\hline Regime FE & Yes & Yes & Yes & Yes & Yes & Yes \\
\hline Observations & 1456 & 1088 & 369 & 1456 & 1088 & 369 \\
\hline Countries & 71 & 65 & 32 & 71 & 65 & 32 \\
\hline Within $\mathrm{R}^{2}$ & .363 & .335 & .518 & .363 & .336 & .514 \\
\hline F statistic & 5.85 & 6.29 & - & 7.81 & 6.85 & - \\
\hline \multicolumn{7}{|l|}{ Only democracies } \\
\hline Terrorism & $\begin{array}{l}.001 \\
(.008)\end{array}$ & $\begin{array}{l}-.006 \\
(.008)\end{array}$ & $\begin{array}{l}.023^{*} \\
(.013)\end{array}$ & $\begin{array}{l}-.002 \\
(.002)\end{array}$ & $\begin{array}{l}-.004 * * \\
(.002)\end{array}$ & $\begin{array}{l}.005 \\
(.016)\end{array}$ \\
\hline Constitutional independence & $\begin{array}{l}.135 \\
(.092)\end{array}$ & $\begin{array}{l}.103 \\
(.076)\end{array}$ & $\begin{array}{l}-.025 \\
(.149)\end{array}$ & $\begin{array}{l}.136 \\
(.093)\end{array}$ & $\begin{array}{l}.111 \\
(.079)\end{array}$ & $\begin{array}{l}.124 \\
(.323)\end{array}$ \\
\hline Terrorism* const. independence & $\begin{array}{l}-.004 \\
(.013)\end{array}$ & $\begin{array}{l}.003 \\
(.014)\end{array}$ & $\begin{array}{l}-.037 * * \\
(.015)\end{array}$ & $\begin{array}{l}-.001 \\
(.005)\end{array}$ & $\begin{array}{l}-.003 \\
(.005)\end{array}$ & $\begin{array}{l}.008 \\
(.017)\end{array}$ \\
\hline Emergency allowance & $\begin{array}{l}.019 \\
(.019)\end{array}$ & & & $\begin{array}{l}.019 \\
(.019)\end{array}$ & & \\
\hline Terrorism* emergency & $\begin{array}{l}.030^{*} \\
(.018)\end{array}$ & & & $\begin{array}{l}.031 * \\
(.016)\end{array}$ & & \\
\hline Terrorism* emergency* independence & $\begin{array}{l}-.049 * * \\
(.022)\end{array}$ & & & $\begin{array}{l}-.051^{* *} \\
(.019)\end{array}$ & & \\
\hline Observations & 1347 & 1017 & 331 & 1347 & 1017 & 331 \\
\hline Countries & 67 & 61 & 30 & 67 & 61 & 30 \\
\hline Within $\mathrm{R}^{2}$ & .325 & .349 & .506 & .326 & .351 & .500 \\
\hline F statistic & - & - & - & - & 5.48 & \\
\hline
\end{tabular}

$* * * p<.01 ; * * p<.05 ; * p<.10$. The results in columns 2 and 5 are obtained in a subsample of observations for which the emergency provisions do not allow for restrictions of media freedom during states of emergency; the estimates in columns 3 and 6 are obtained for a subsample of observations for which the emergency provisions do allow for restrictions of media freedom during states of emergency 


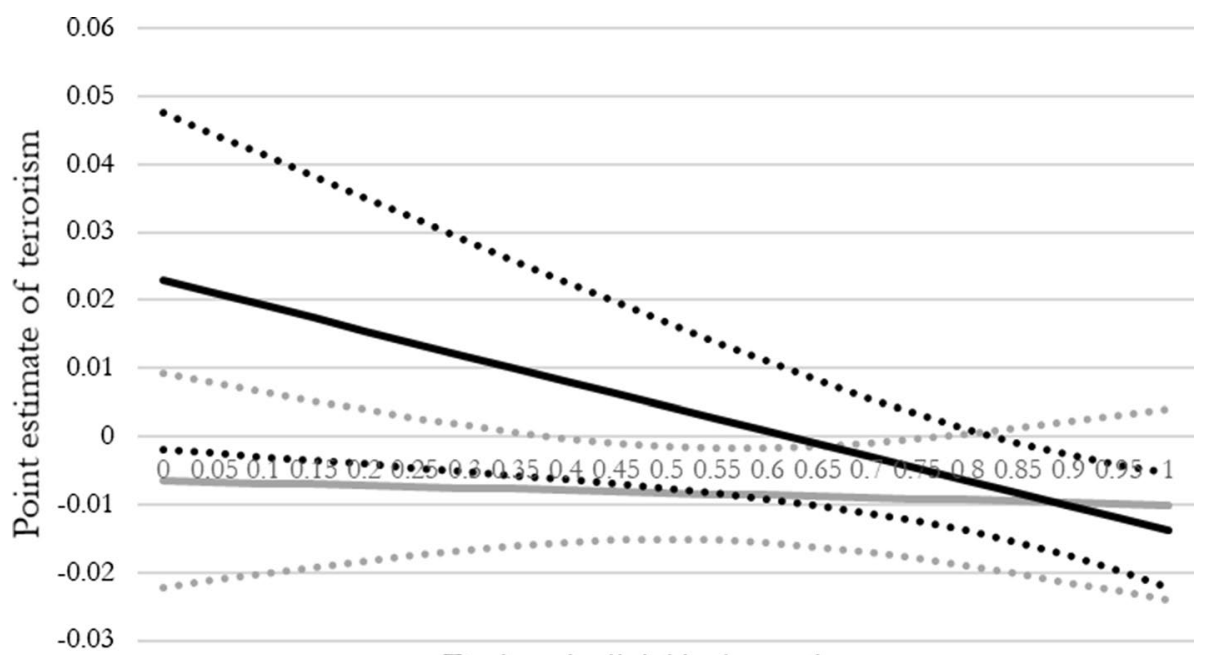

De jure judicial independence

No emergency allowance $\quad$ With emergency allowance

Fig. 4 Effects of terrorism, triple interacted conditions

the size of the estimate, but a much more precisely estimated effect in countries where the emergency provisions allow the government to curtail media freedom.

In Table 3, we therefore take a further step towards identifying the constitutional conditions under which terrorist attacks lead to reductions in media freedom. We do so by introducing a triple interaction between our two terrorism measures, the index of constitutional independence, and the dummy capturing whether the emergency provisions allow press restrictions during states of emergency.

We find that a terrorist event occurring in a country allowing restrictions on media freedom during a state of emergency and that enjoys a high degree of formal court independence is likely to lead to a considerable decline in actual media freedom. That reduction is slightly more pronounced when terrorist events are captured by their numbers (column 1) than by their severities (column 4); we illustrate those differences in Fig. 4. While we find no evidence of significant effects on the number of events in countries with no emergency provisions and no or little constitutional protections, we find significant effects for more severe events, captured by the number of victims killed by terrorists. Yet, the triple interaction indicates that terrorist attacks lead to much larger reductions in de facto media freedom in countries where the emergency provisions allow for press restrictions and the constitution more clearly protects the independence of the courts. While the results also appear to indicate that emergency provisions per se lead to more media freedom, that result must be interpreted as significant only when the constitutional independence of the courts is very limited, which is only the case for 4 years in a single country: Portugal in the years immediately before democratization in the mid-1970s.

In columns 2-3 and 5-6 in Table 3, we substantiate our results by restricting the sample to observations in which the emergency provisions do not allow for restricting media freedom (columns 2 and 5) or observations in which they do (columns 3 and 6), which allows us to determine if the results differ depending on the basic characteristic of the emergency 
provisions. We observe that while media freedom is unaffected by the number of terrorist events when the constitution does not allow restraints during emergencies, events do lead to some abridgment of press freedom when it does, and when the constitution ostensibly protects the independence of the high courts. Conversely, we find that more severe attacks, i.e., those that lead to more people being killed, are associated with further restrictions when the constitution does not allow limits in emergencies. When it does, we find no evidence that terrorist events lead to restrictions on media freedom.

In further tests, which we report in the appendix, we separate terrorist events based on whether they are directed specifically against the government or military/police forces and we separate the attacks in which the terrorists used heavier arms and those involving multiple targets. In the former type, politicians or public officials are targeted directly, which may for personal reasons make them more likely to react, while heavily armed attacks also may pose more serious threats to the incumbent regime. We nevertheless find no significant differences across those specific types of terrorist events, and quite weak effects when focusing on the small number of attacks involving multiple targets; we therefore refrain from further comment. ${ }^{15}$ In further tests (not shown), we also conclude that the main results are not driven by, for example, Israel, which has been in a continuous state of emergency, and that our results are independent of whether the government actually declared a state of emergency or not. The main results in Table 3 thus are robust to intuitive tests and appear generalizable under the specific constitutional conditions identified in the table.

\section{Conclusions and outlook}

In this paper, we look into the consequences of terrorist attacks for media freedom. More specifically, we ask whether constitutional guarantees of a free media mitigate the (expected) downturn in media freedom following a terrorist attack and, thus, whether a specific kind of constitutional protection (in this case of the media) actually does lead to stronger protections. Put differently, we employ terrorist attacks as 'stress tests' of the relevance of constitutional safeguarding of media freedom.

The results are quite sobering. As expected, more and, in particular, more severe terrorist events lead to reductions in media freedom. That effect is independent of the specific way of accounting terrorist activities (the number of incidents versus their severity). When the independence of the highest court as specified in the constitution is taken explicitly into account and is interacted with our terrorism variables, it turns out that terrorist events (no matter how accounted for explicitly) become significant in explaining restrictions of media freedom, the stronger are the constitutional guarantees of high court independence. In other words, in robust constitutional systems, terrorist attacks lead to substantial reductions in media freedom. Legal scholars have discussed the possibility that constitutional restrictions on government do not bind governmental hands, ever since James Madison expressed his concern that constitutional rights and other limits on government behavior would create mere "parchment barriers" in Federalist No. 48 (Levinson 2011 discusses the "puzzle of constitutional commitment" from a legal scholar's point of view). It seems that Madison's concerns not only have been vindicated

\footnotetext{
15 We refrain from testing whether effects differ if the terrorist organizations launching attacks are 'home grown', as too few incidents of domestic terrorism exist in countries outside of Latin America to provide solid identification. Yet, we also note that the attacks in our sample are country-specific and not transnational events: in further tests, we find no clear evidence that reductions in media freedom spill-over across borders.
} 
with regard to media freedom, but that other parchment barriers nominally ensuring the independence of the judiciary interact perniciously with de jure media protections.

Most constitutions contain explicit emergency provisions. They regulate the conditions under which government is allowed to declare a state of emergency and what additional powers it has under those conditions. Based on a dummy variable indicating whether government is allowed to tinker with media freedom during a state of emergency, we find that provisions allowing for curtailing media freedom in those times indeed are associated with less de facto media freedom.

Interacting terrorist events with both de jure court independence and emergency provisions-which we introduce in order to allow for heterogeneous effects that depend on constitutional performance and the potential unconstitutionality of restricting media freedom-indicates that terrorist attacks lead to much larger reductions in de facto media freedom in countries where the emergency provisions allow such restrictions and the constitution more clearly protects the independence of the courts.

A remaining question is the transmission channel reflected in our findings. We prefer to remain agnostic, as we see two interpretations that both are consistent with our empirical results. First, it is possible to interpret the findings as evidence that politicians limit media freedom in order to protect citizens from further terrorist attacks. However, such an interpretation requires that politicians believe that curbing media freedom is an effective way of enhancing the citizenry's security. We note that little evidence exists supporting such a belief although politicians may still hold it (Bjørnskov and Voigt in press). A benevolent interpretation of the effects also would imply that the restrictions on the press will be temporary, to be lifted once the imminent terrorist threat has passed. Yet, we observe that changes in de facto media freedom tend to persist. ${ }^{16}$ That observation leaves open two options that are both consistent with the overall findings.

First, an interpretation in which the findings reflect opportunistic political behavior is consistent with the results. Leading politicians as well as some government agencies have interest in gaining additional power and avoiding criticism, and substantial de jure constitutionalization of the judiciary may reflect a state in which such influence can be enforced through formal mechanisms (Dragu 2011). However, we must emphasise that that interpretation is difficult to reconcile with the evidence that terrorist attacks as well as emergency reactions to such attacks appear unpopular with most voters (Gassebner et al. 2008; Bjørnskov and Voigt in press).

A second, alternative interpretation, nevertheless also is consistent with the findings. If one interprets substantial constitutionalization as reflected in our de jure index of judicial independence as an indication of the independence of government agencies in total, a side effect of independence may be a lack of political or bureaucratic coordination across agencies. That interpretation implies that the results can be explained by multiple agencies all reacting to terrorist threats in an uncoordinated manner. As such, substantial abridgments of media freedom are a result of a bureaucratic overreaction similar to the tragedy of the commons or voracity effects (cf. Tornell and Lane 1999), and not political opportunism.

To sum up the results, we find that governments' inclinations to reduce media freedom after a terrorist event cannot easily be prevented by constitutionally protecting judicial independence or by specific emergency provisions. At least some of the constitutional provisions

\footnotetext{
${ }^{16}$ In further tests (not shown), we even find that lagged and contemporaneous terrorist events have approximately the same effects on press freedom, as indicated by the main results in Table 3 . That finding also is consistent with limits on press freedom becoming permanent and, thus, with an interpretation that our findings are evidence of opportunistic political behavior.
} 
that ostensibly protect the media therefore appear to be mere window-dressing that governments can exploit during and after terrorist events. In other words, at least some governments might have an interest in terrorist incidents occurring because attacks allow them to repress the media and apparently do it within constitutional bounds protected by an ostensibly independent high court.

Our findings thus point towards two interesting questions fur future research. First, what makes governments and other political actors constitutionalize media freedom and to adopt other features of the institutional framework in the first place? Second, do reductions in media freedom occur in isolation or are they accompanied by restrictions on other civil liberties? In other words, while we find limits on media freedom under specific constitutional circumstances, do those effects generalize to other repressive government actions?

Acknowledgements Open Access funding provided by Projekt DEAL. We thank Tommy Krieger, Peter Nannestad, Thomas Stratmann, José Tavares and participants at the 2019 Danish Public Choice Workshop (Aarhus) and the 2019 Silvaplana workshop as well two reviewers of this journal for helpful comments on an earlier version. Bjørnskov also thanks the Jan Wallander and Tom Hedelius Foundation for funding part of this research.

Open Access This article is licensed under a Creative Commons Attribution 4.0 International License, which permits use, sharing, adaptation, distribution and reproduction in any medium or format, as long as you give appropriate credit to the original author(s) and the source, provide a link to the Creative Commons licence, and indicate if changes were made. The images or other third party material in this article are included in the article's Creative Commons licence, unless indicated otherwise in a credit line to the material. If material is not included in the article's Creative Commons licence and your intended use is not permitted by statutory regulation or exceeds the permitted use, you will need to obtain permission directly from the copyright holder. To view a copy of this licence, visit http://creativecommons.org/licenses/by/4.0/.

\section{Appendix 1: The press freedom measure}

We use the Freedom House (2017) measure of press freedom as our measure of media freedom, which conceptually is based on Article 19 of the Universal Declaration of Human Rights. The index is scored by expert coders at Freedom House on 23 methodology questions that aim to cover the multiple ways in which governments and private actors can place pressure and limits on the flow of information to the public and the ability of the media to operate freely and without potential repercussions. The 23 questions cover three separate elements: the legal, political and economic environments of the media; recent editions offer three separate sub-indices: (1) the extent to which media freedom is restricted by laws and regulations and their de facto enforcement in practice; (2) the extent to which media content is subject to political control, which includes editorial independence, absence of censorship, information availability, and the de facto freedom of journalists to perform their jobs; and (3) the extent to which economic characteristics, such as the industrial and ownership structure of the media, impediments to production, distribution and advertisement, and possible corruption can limit the media's freedom. The overall index of press freedom thus includes expert assessments of a broad array of mechanisms through which government and private actors could influence the media's freedom.

\section{Appendix 2}

See Tables A1, A2 and Fig. 5. 
Table A1 Country averages

\begin{tabular}{|c|c|c|c|c|c|}
\hline Country & Press freedom & Censorship & Log killed & Log events & $\begin{array}{l}\text { Const. } \\
\text { independ- } \\
\text { ence }\end{array}$ \\
\hline Albania & 0.48 & 0.00 & 0.40 & 0.69 & 0.60 \\
\hline Antigua and Barbuda & 0.63 & 1.00 & 0.00 & 0.00 & 0.25 \\
\hline Argentina & 0.61 & 0.85 & 0.33 & 1.01 & 0.60 \\
\hline Armenia & 0.40 & 1.00 & 0.43 & 0.47 & 0.60 \\
\hline Australia & 0.88 & 1.00 & 0.12 & 0.71 & 0.44 \\
\hline Austria & 0.85 & 1.00 & 0.13 & 0.68 & 0.57 \\
\hline Azerbaijan & 0.24 & 0.05 & 0.42 & 0.56 & 0.60 \\
\hline Bahamas & 0.89 & 1.00 & 0.03 & 0.09 & 0.51 \\
\hline Barbados & 0.87 & 1.00 & 0.00 & 0.00 & 0.41 \\
\hline Belarus & 0.15 & 0.00 & 0.17 & 0.34 & 0.62 \\
\hline Belgium & 0.94 & 0.00 & 0.12 & 0.59 & 0.76 \\
\hline Belize & 0.81 & 1.00 & 0.00 & 0.07 & 0.51 \\
\hline Bolivia & 0.69 & 0.75 & 0.12 & 0.51 & 0.63 \\
\hline Bosnia and Herzegovina & 0.48 & 1.00 & 0.52 & 1.33 & 0.13 \\
\hline Brazil & 0.65 & 0.60 & 0.79 & 1.08 & 0.60 \\
\hline Bulgaria & 0.67 & 0.00 & 0.44 & 0.74 & 0.84 \\
\hline Canada & 0.87 & 1.00 & 0.07 & 0.95 & 0.13 \\
\hline Chile & 0.76 & 0.75 & 0.14 & 1.45 & 0.60 \\
\hline Colombia & 0.45 & 0.80 & 5.28 & 4.76 & 0.63 \\
\hline Costa Rica & 0.87 & 0.00 & 0.16 & 0.10 & 1.00 \\
\hline Croatia & 0.57 & 0.35 & 0.23 & 0.58 & 0.88 \\
\hline Cuba & 0.06 & 1.00 & 0.14 & 0.32 & 0.50 \\
\hline Cyprus & 0.83 & 1.00 & 0.12 & 0.60 & 0.32 \\
\hline Czech Republic & 0.84 & 0.65 & 0.16 & 0.48 & 0.60 \\
\hline Denmark & 0.94 & 0.00 & 0.00 & 0.24 & 0.38 \\
\hline Dominica & 0.84 & 1.00 & 0.00 & 0.03 & 0.38 \\
\hline Dominican Republic & 0.67 & 0.20 & 0.19 & 0.32 & 0.61 \\
\hline Ecuador & 0.56 & 1.00 & 0.20 & 1.06 & 0.72 \\
\hline El Salvador & 0.61 & 0.00 & 0.43 & 0.42 & 0.63 \\
\hline Estonia & 0.86 & 0.00 & 0.10 & 0.29 & 0.85 \\
\hline Finland & 0.93 & 0.95 & 0.12 & 0.14 & 0.69 \\
\hline France & 0.81 & 1.00 & 0.73 & 3.33 & 0.63 \\
\hline Georgia & 0.46 & 1.00 & 1.63 & 1.88 & 0.60 \\
\hline Germany & 0.89 & 0.00 & 0.62 & 1.99 & 0.60 \\
\hline Greece & 0.71 & 0.35 & 0.34 & 3.09 & 0.60 \\
\hline Grenada & 0.83 & 1.00 & 0.00 & 0.00 & 0.13 \\
\hline Guatemala & 0.44 & 0.00 & 1.12 & 1.22 & 0.63 \\
\hline Guyana & 0.75 & 1.00 & 0.34 & 0.28 & 0.57 \\
\hline Honduras & 0.49 & 1.00 & 0.86 & 0.76 & 0.63 \\
\hline Hungary & 0.75 & 1.00 & 0.16 & 0.48 & 0.93 \\
\hline Iceland & 0.93 & 0.25 & 0.00 & 0.03 & 0.13 \\
\hline Ireland & 0.88 & 1.00 & 0.25 & 1.17 & 0.72 \\
\hline Israel & 0.74 & 1.00 & 3.28 & 3.51 & 0.00 \\
\hline
\end{tabular}


Table A1 (continued)

\begin{tabular}{|c|c|c|c|c|c|}
\hline Country & Press freedom & Censorship & Log killed & Log events & $\begin{array}{l}\text { Const. } \\
\text { independ- } \\
\text { ence }\end{array}$ \\
\hline Italy & 0.73 & 0.35 & 0.19 & 1.84 & 0.38 \\
\hline Jamaica & 0.89 & 1.00 & 0.24 & 0.26 & 0.79 \\
\hline Japan & 0.83 & 0.00 & 0.25 & 0.97 & 0.92 \\
\hline Korea, Republic of & 0.74 & 0.00 & 0.03 & 0.27 & 0.82 \\
\hline Latvia & 0.81 & 0.15 & 0.07 & 0.36 & 0.63 \\
\hline Lithuania & 0.83 & 0.35 & 0.03 & 0.16 & 0.60 \\
\hline Luxembourg & 0.93 & 0.00 & 0.00 & 0.07 & 0.35 \\
\hline Macedonia & 0.54 & 0.00 & 0.50 & 1.03 & 0.75 \\
\hline Malta & 0.85 & 1.00 & 0.03 & 0.07 & 0.35 \\
\hline Mexico & 0.49 & 0.00 & 2.15 & 1.82 & 0.82 \\
\hline Moldova & 0.44 & 0.00 & 0.09 & 0.26 & 0.63 \\
\hline Montenegro & 0.65 & 0.88 & 0.04 & 0.13 & 0.80 \\
\hline Netherlands & 0.91 & 1.00 & 0.21 & 0.73 & 0.38 \\
\hline New Zealand & 0.93 & 1.00 & 0.00 & 0.28 & 0.13 \\
\hline Nicaragua & 0.57 & 0.35 & 0.53 & 0.63 & 0.60 \\
\hline Norway & 0.96 & 1.00 & 0.25 & 0.28 & 0.25 \\
\hline Panama & 0.65 & 0.00 & 0.33 & 0.42 & 0.69 \\
\hline Paraguay & 0.47 & 0.00 & 0.34 & 0.71 & 0.60 \\
\hline Peru & 0.55 & 0.55 & 2.39 & 1.79 & 0.63 \\
\hline Poland & 0.79 & 0.15 & 0.05 & 0.42 & 0.79 \\
\hline Portugal & 0.88 & 0.00 & 0.05 & 0.16 & 0.88 \\
\hline Romania & 0.59 & 0.45 & 0.00 & 0.07 & 0.38 \\
\hline Russia & 0.32 & 0.00 & 5.03 & 4.42 & 0.60 \\
\hline Serbia & 0.50 & 0.30 & 1.00 & 1.61 & 0.75 \\
\hline Singapore & 0.35 & 1.00 & 0.03 & 0.03 & 0.35 \\
\hline Slovak Republic & 0.75 & 1.00 & 0.19 & 0.38 & 0.82 \\
\hline Slovenia & 0.79 & 1.00 & 0.03 & 0.17 & 0.63 \\
\hline Spain & 0.82 & 0.00 & 1.52 & 3.10 & 0.60 \\
\hline Suriname & 0.76 & 1.00 & 0.00 & 0.09 & 0.35 \\
\hline Sweden & 0.95 & 1.00 & 0.07 & 0.61 & 0.25 \\
\hline Switzerland & 0.94 & 0.00 & 0.20 & 0.64 & 0.63 \\
\hline Taiwan & 0.79 & 1.00 & 0.20 & 0.46 & 0.60 \\
\hline Trinidad \&Tobago & 0.78 & 1.00 & 0.14 & 0.34 & 0.57 \\
\hline Turkey & 0.42 & 1.00 & 3.78 & 3.69 & 1.00 \\
\hline Ukraine & 0.47 & 0.10 & 0.31 & 0.96 & 0.88 \\
\hline United Kingdom & 0.84 & 1.00 & 1.75 & 3.67 & 0.47 \\
\hline United States & 0.88 & 1.00 & 1.78 & 3.12 & 0.35 \\
\hline Uruguay & 0.77 & 0.00 & 0.00 & 0.24 & 0.38 \\
\hline Venezuela & 0.42 & 0.00 & 0.58 & 1.17 & 0.66 \\
\hline
\end{tabular}


Table A2 Results, different types of attacks

\begin{tabular}{|c|c|c|c|c|c|c|c|c|}
\hline \multirow[t]{3}{*}{ Target/type } & \multicolumn{8}{|c|}{ Log no. of events } \\
\hline & \multicolumn{2}{|c|}{ Government } & \multicolumn{2}{|c|}{ Police/military } & \multicolumn{2}{|c|}{ Heavily armed } & \multicolumn{2}{|c|}{ Multiple targets } \\
\hline & 1 & 2 & 3 & 4 & 5 & 6 & 7 & 8 \\
\hline \multicolumn{9}{|l|}{ Full baseline included } \\
\hline Terrorism & $\begin{array}{l}-.004 \\
(.004)\end{array}$ & $\begin{array}{l}.005 \\
(.013)\end{array}$ & $\begin{array}{l}-.003 \\
(.004)\end{array}$ & $\begin{array}{l}-.004 \\
(.017)\end{array}$ & $\begin{array}{l}-.003 \\
(.003)\end{array}$ & $\begin{array}{l}.006 \\
(.008)\end{array}$ & $\begin{array}{l}-.006 \\
(.008)\end{array}$ & $\begin{array}{l}.012 \\
(.017)\end{array}$ \\
\hline $\begin{array}{l}\text { Constitutional const. inde- } \\
\text { pendence }\end{array}$ & $\begin{array}{l}.125 \\
(.091)\end{array}$ & $\begin{array}{l}.129 \\
(.091)\end{array}$ & $\begin{array}{l}.126 \\
(.092)\end{array}$ & $\begin{array}{l}.125 \\
(.090)\end{array}$ & $\begin{array}{l}.124 \\
(.092)\end{array}$ & $\begin{array}{l}.134 \\
(.093)\end{array}$ & $\begin{array}{l}.124 \\
(.092)\end{array}$ & $\begin{array}{l}.125 \\
(.091)\end{array}$ \\
\hline Terrorism $*$ independence & & $\begin{array}{l}-.013 \\
(.022)\end{array}$ & & $\begin{array}{l}.000 \\
(.031)\end{array}$ & & $\begin{array}{l}-.012 \\
(.015)\end{array}$ & & $\begin{array}{l}-.016 \\
(.036)\end{array}$ \\
\hline Emergency allowance & $\begin{array}{l}.020 \\
(.018)\end{array}$ & $\begin{array}{l}.019 \\
(.018)\end{array}$ & $\begin{array}{l}.021 \\
(.018)\end{array}$ & $\begin{array}{l}.017 \\
(.019)\end{array}$ & $\begin{array}{l}.020 \\
(.018)\end{array}$ & $\begin{array}{l}.018 \\
(.019)\end{array}$ & $\begin{array}{l}.020 \\
(.018)\end{array}$ & $\begin{array}{l}.022 \\
(.018)\end{array}$ \\
\hline Terrorism * emergency & & $\begin{array}{l}.044^{*} \\
(.024)\end{array}$ & & $\begin{array}{l}.065^{* *} \\
(.031)\end{array}$ & & $\begin{array}{l}.037 * \\
(.019)\end{array}$ & & $\begin{array}{l}.000 \\
(.028)\end{array}$ \\
\hline $\begin{array}{l}\text { Terrorism * emergency * } \\
\text { independence }\end{array}$ & & $\begin{array}{l}-.071 * * \\
(.031)\end{array}$ & & $\begin{array}{l}-.079 * * \\
(.039)\end{array}$ & & $\begin{array}{l}-.056^{* * *} \\
(.024)\end{array}$ & & $\begin{array}{l}-.039 \\
(.042)\end{array}$ \\
\hline Annual FE & Yes & Yes & Yes & Yes & Yes & Yes & Yes & Yes \\
\hline Country FE & Yes & Yes & Yes & Yes & Yes & Yes & Yes & Yes \\
\hline Regime FE & Yes & Yes & Yes & Yes & Yes & Yes & Yes & Yes \\
\hline Observations & 1347 & 1347 & 1347 & 1347 & 1347 & 1347 & 1347 & 1347 \\
\hline Countries & 67 & 67 & 67 & 67 & 67 & 67 & 67 & 67 \\
\hline Within $\mathrm{R}^{2}$ & .322 & .327 & .321 & .324 & .321 & .327 & .321 & .328 \\
\hline F statistic & - & - & - & - & - & - & - & \\
\hline
\end{tabular}

The results in columns 2 and 5 are obtained in a subsample of observations for which the emergency provisions do not allow for restrictions of media freedom during states of emergency; the estimates in columns 3 and 6 are obtained for a subsample of observations for which the emergency provisions do allow for restrictions of media freedom during states of emergency

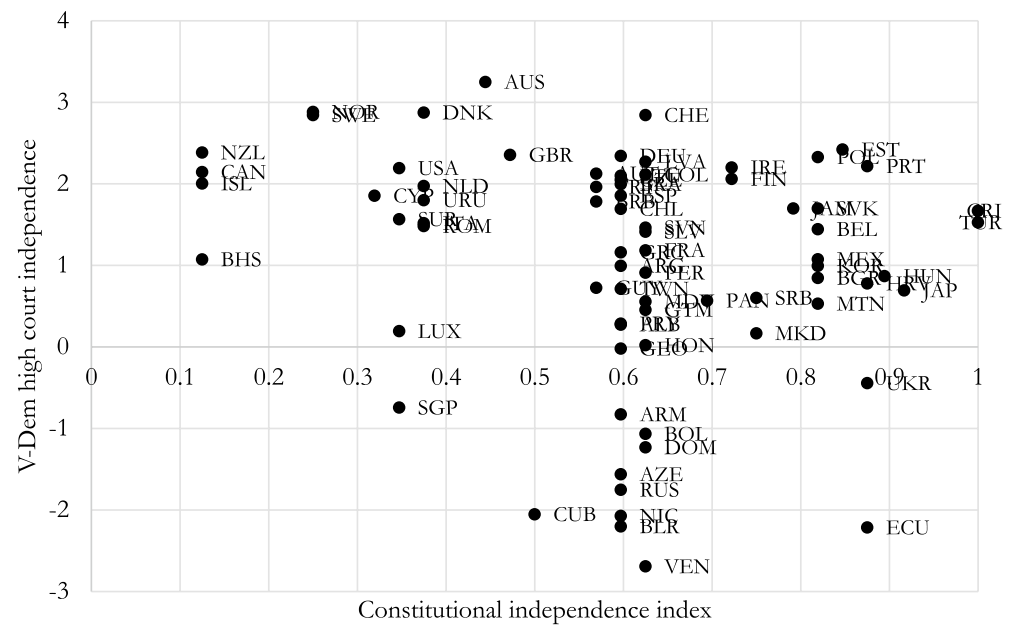

Fig. 5 De jure and de facto judiciary independence 


\section{References}

Amnesty International. (2018). Spain: Counter-terror law used to crush satire and creative expression online. Press release, Amnesty International, March 13. Retrieved November, 2018, available at https:// www.amnesty.org/en/latest/news/2018/03/spain-counter-terror-law-used-to-crush-satire-and-creativeexpression-online/.

Asal, V., \& Hoffman, A. M. (2016). Media effects: Do terrorist organizations launch foreign attacks in response to levels of press freedom or press attention? Conflict Management and Peace Science, 33(4), 381-399.

Becker, L. B., Vlad, T., \& Nusser, N. (2007). An evaluation of press freedom indicators. International Communication Gazette, 69, 5-28.

Berggren, N., \& Bjørnskov, C. (2017). The market-promoting and market-preserving role of social trust in reforms of policies andinstitutions. Southern Economic Journal, 84(1), 3-25.

Bernholz, P. (1979). Freedom and constitutional economic order. Zeitschrift für die gesamte Staatswissenschaft/Journal of Institutional and Theoretical Economics, (H. 3), 510-532.

Besley, T., \& Burgess, R. (2001). Political agency, government responsiveness and the role of the media. European Economic Review, 45(4-6), 629-640.

Besley, T., \& Prat, A. (2006). Handcuffs for the grabbing hand? Media capture and government accountability. American Economic Review, 96(3), 720-736.

Bjørnskov, C. (2019). The political economy of trust. Chapter 32. In R. Congleton, B. Grofman, \& S. Voigt (Eds.), Oxford handbook of public choice (Vol. 1, pp. 628-648). Oxford: Oxford University Press.

Bjørnskov, C., Gutmann, J., \& Freytag, A. (2018). Coups, regime transition, and the dynamics of press freedom. CESIfo working paper no. 7198, CESIfo, Munich.

Bjørnskov, C., \& Rode, M. (Forthcoming). Regime types and regime change: A new dataset on democracy, coups, and political institutions. Review of International Organizations. Retrieved November, 2018, data available at http://www.christianbjoernskov.com/bjoernskovrodedata/. (In press).

Bjørnskov, C., \& Voigt, S. (2018). The architecture of emergency constitutions. International Journal of Constitutional Law, 16, 101-127.

Bjørnskov, C., \& Voigt, S. (Forthcoming). When does terror induce a states of emergency? And what are the effects? Journal of Conflict Resolution (in press).

Brunetti, A., \& Weder, B. (2003). A free press is bad news for corruption. Journal of Public Economics, 87(7), 1801-1824.

Buchanan, J. M., \& Tullock, G. (1962). The calculus of consent. Ann Arbor: University of Michigan press.

Cheibub, J. A., Gandhi, J., \& Vreeland, J. R. (2010). Democracy and dictatorship revisited. Public Choice, $143,67-101$.

Chowdhury, S. K. (2004). The effect of democracy and press freedom on corruption: an empirical test. Economics Letters, 85(1), 93-101.

Coppedge, M., Lindberg, S., Skaaning, S.-E., \& Teorell, J. (2016). Measuring high level democratic principles using the V-Dem data. International Political Science Review, 37, 580-593.

Djankov, S., McLiesh, C., Nenova, T., \& Shleifer, A. (2003). Who owns the media? Journal of Law and Economics, 46(2), 341-382.

Dragu, T. (2011). Is there a trade-off between security and liberty? Executive bias, privacy protection, and terrorism prevention. American Political Science Review, 105, 64-78.

Egorov, G., Guriev, S., \& Sonin, K. (2009). Why resource-poor dictators allow freer media: A theory and evidence from panel data. American Political Science Review, 103, 645-668.

Elkins, Z., Ginsburg, T., \& Melton, J. (2009). The endurance of national constitutions. Cambridge: Cambridge University Press.

Encyclopædia Britannica. (2018). Censorship. Online encyclopedia. Retrieved January, 2018, from https:// www.britannica.com/topic/censorship\#ref358885.

Enders, W., \& Sandler, T. (2012). The political economy of terrorism. Cambridge: Cambridge University Press.

Engerman, S. L., \& Sokoloff, K. L. (2008). Debating the role of institutions in political and economic development: Theory, history, and findings. Annual Review of Political Science, 11, 119-135.

Feenstra, R. C., Inklaar, R., \& Timmer, M. P. (2015). The next generation of the Penn World Table. American Economic Review, 105(10), 3150-3182.

Gassebner, M., Jong-A-Pin, R., \& Mierau, J. O. (2008). Terrorism and electoral accountability: One strike, you're out! Economics Letters, 100, 126-129.

Gehlbach, S., \& Sonin, K. (2014). Government control of the media. Journal of Public Economics, 118, 163-171. 
GTD. (2017). Global terrorism database codebook: Inclusion criteria and variables. College Park, MD: University of Maryland. Retrieved November, 2017, database available at https://www.start.umd.edu/ $\mathrm{gtd} /$.

Gutmann, J., \& Voigt, S. (in press). Judicial independence in the EU: a puzzle. European Journal of Law and Economics.

Hillman, A. L., \& Potrafke, N. (2018). Economic freedom and religion: An empirical investigation. Public Finance Review, 46(2), 249-275.

Hoffman, A. M., Shelton, C., \& Cleven, E. (2013). Press freedom, publicity, and the cross-national incidence of transnational terrorism. Political Research Quarterly, 66, 896-909.

House, Freedom. (2017). Freedom in the press 2017: Press freedom's dark horizon. Washington DC: Freedom House.

Jetter, M. (2017). The effect of media attention on terrorism. Journal of Public Economics, 153, 32-48.

Kellam, M., \& Stein, E. A. (2016). Silencing critics: Why and how presidents restrict media freedom in democracies. Comparative Political Studies, 49(1), 36-77.

Levinson, D. J. (2011). Parchment and politics: The positive puzzle of constitutional commitment. Harvard Law Review, 124(3), 657-746.

Linzer, D. A., \& Staton, J. K. (2015). A global measure of judicial independence, 1948-2012. Journal of Courts and Law, 3, 223-256.

McMillan, J., \& Zoido, P. (2004). How to subvert democracy: Montesinos in Peru. Journal of Economic Perspectives, 18(4), 69-92.

Nizalova, O. Y., \& Murtazashvili, I. (2016). Exogenous treatment and endogenous factors: Vanishing of omitted variable bias on the interaction term. Journal of Econometric Methods, 5, 71-77.

Rohner, D., \& Frey, B. S. (2007). Blood and ink! The common-interest-game between terrorists and the media. Public Choice, 133(1-2), 129-145.

Sandler, T. (2014). The analytical study of terrorism: Taking stock. Journal of Peace Research, 51, $257-271$.

Sen, A. (1984). Food Battles: Conflicts in the access to food. Food and Nutrition, 10, 81-89.

Stier, S. (2015). Democracy, autocracy and the news: The impact of regime type on media freedom. Democratization, 22(7), 1273-1295.

Sunstein, C. R., \& Zeckhauser, R. (2011). Overreaction to fearsome risks. Environmental \& Resource Economics, 48(3), 435-449.

Tornell, A., \& Lane, P. R. (1999). The voracity effect. American Economic Review, 89(1), 22-46.

United Nations. (1948). Universal declaration on human rights. New York: The United Nations.

VonDoepp, P., \& Young, D. J. (2012). Assaults on the fourth estate: Explaining media harassment in Africa. Journal of Politics, 75(1), 36-51.

Publisher's Note Springer Nature remains neutral with regard to jurisdictional claims in published maps and institutional affiliations. 